\title{
Walter Benjamin e a aventura surrealista ${ }^{1}$
}

\author{
Danilo Mataveli ${ }^{i}$
}

\section{RESUMO}

As experiências artísticas do movimento surrealista na primeira metade do século XX foram determinantes para a formulação de conceitos-chave na obra de Walter Benjamin. Foi a partir dessas experiências que o filósofo pensou noções como a iluminação profana, a embriaguez e a possibilidade de uma política poética. Neste ensaio, procuramos rastrear em diferentes textos do autor as principais ideias e fundamentos para a elaboração dessas categorias. Também voltamos aos precursores do surrealismo, Baudelaire e Rimbaud, numa espécie de leitura arqueológica em busca das referências indicadas por Walter Benjamin em seus trabalhos.

Palavras-chave: Walter Benjamin; Surrealismo; Embriaguez; Iluminação profana.

\section{RESUMEN}

Las experiencias artísticas del movimiento surrealista de la primera mitad del siglo XX fueron determinantes para la formulación de algunos conceptos clave en la obra de Walter Benjamin. Fue a partir de estas experiencias que el filósofo pensó en nociones como la iluminación profana, la embriaguez y la posibilidad de una política poética. En este ensayo, tratamos de rastrear en diferentes textos del autor las principales ideas y fundamentos para la elaboración de estas categorías. También volvemos a los precursores del surrealismo, Baudelaire y Rimbaud, en una especie de lectura arqueológica en busca de las referencias indicadas por Walter Benjamin en sus obras.

Palabras clave: Walter Benjamin; Surrealismo; Embriaguez; Iluminación profana.

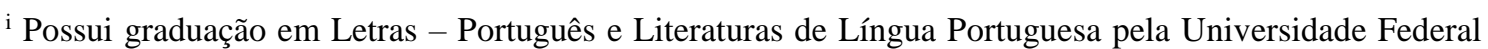
do Rio de Janeiro (2016) e mestrado em Ciência da Literatura pela Universidade Federal do Rio de Janeiro (2019). Atualmente é doutorando em Ciência da Literatura na Universidade Federal do Rio de Janeiro, estudante do Conselho Nacional de Desenvolvimento Científico e Tecnológico, coordenador adjunto do Núcleo Poesia do PACC da Universidade Federal do Rio de Janeiro e Membro Organizador do Laboratório da Palavra da Universidade Federal do Rio de Janeiro. Tem experiência na área de Letras, com ênfase em Teoria Literária

E-mail: matavelidanilo@gmail.com
} 


\section{DOCUMENTO, BLUFF, FALSIFICAÇÃO, ̀̀ MANEIRA DE CONTEXTUALIZAÇÃO HISTÓRICA}

Quando publicou o seu principal ensaio sobre o movimento surrealista, em 1929, por volta de uma década após o término da Primeira Guerra Mundial (1914-1918) e após a consolidação da Revolução Russa de 1917, Walter Benjamin poderia estar tomado por um forte entusiasmo com relação ao avanço das forças progressistas representadas pelo Partido Comunista no campo político internacional. Essas forças progressistas, movidas pela "energia revolucionária" do proletariado, seriam tomadas como base para as manifestações políticas de alguns membros do movimento surrealista. Benjamin considerava indesculpável a hipótese de um crítico alemão referirse ao surrealismo como um movimento "artístico ou poético", precisamente por conta do distanciamento geral do crítico alemão em relação ao centro cultural do fenômeno. $\mathrm{O}$ movimento surrealista surgia na França em 1919, ano em que a Alemanha violou o Tratado de Versalhes e deu início a uma campanha secreta de rearmamento. No início desse mesmo ano, "Rosa Luxemburgo/ foi assassinada em Berlim. Os assassinos/ a arrebentaram a coronhadas de fuzil/ e a jogaram nas águas de um canal./ No caminho ela perdeu um sapato" (GALEANO, 2015, p. 201).

Rosa Luxemburgo, Karl Liebknecht e Wilhelm Pieck eram líderes do Partido Comunista Alemão. Em 5 de janeiro de 1919, foram presos e levados para interrogatório no Adlon Hotel, em Berlim. Conta-se que eles foram informados de que seriam realocados. Soldados alemães escoltaram Luxemburgo e Liebknecht para fora do prédio, deixando-os inconscientes quando saíram. Pieck conseguiu escapar, enquanto os corpos inconscientes de Luxemburgo e Liebknecht foram levados num jipe militar alemão. Eles foram baleados e jogados num rio.

$\mathrm{O}$ fascismo crescia. "O furor não poupava ninguém: camponeses, operários, intelectuais, funcionários...” (SCHÜTRUMPF, Ibidem, p. 44) Em 1922 - um ano antes do Putsch de Munique, a primeira tentativa de golpe de Estado de Adolf Hitler e do Partido Nazista, ocorrida em 1923 - Albert Einstein fugiu de Berlim para o norte da Alemanha. De lá, o cientista enviou uma carta para a sua irmã Maja, na qual escreveu: “Aqui, ninguém sabe onde estou, e acredita-se que eu esteja viajando. Estão surgindo tempos econômica e politicamente sombrios, então, estou feliz de poder fugir de tudo 
isso" (EM CARTA, 2018, s.p.). Einstein estava temeroso quanto à ascensão do nacionalismo e do antissemitismo no país. "Na ocasião, o físico tinha acabado de saber que seu amigo de longa data e colega judeu Walther Rathenau, ministro do Exterior da Alemanha, fora assassinado por extremistas de direita e que, segundo a polícia, a sua própria vida poderia estar em perigo" (Idem, ibidem). Mais tarde, outro acontecimento decisivo consolidou as preocupações de Einstein:

Em 2 de dezembro de 1925, as mais importantes empresas químicas alemãs formaram o chamado 'Grupo de Interesses da Indústria de Tintas', com sede em Frankfurt. [...] Durante o regime nazista (1933-1945), 350 mil pessoas foram submetidas a trabalhos forçados e pelo menos 20 mil morreram na fábrica do grupo de interesses IG Farben, construída em 1941, nas proximidades do campo de concentração de Auschwitz. Entre outras mercadorias, ela produzia as pastilhas de cianureto usadas nas câmaras de gás pelos nazistas. (GERICKE, 2017, s.p.)

Os nazistas agiam nas sombras, como os espiões de variadas forças que atravessavam os quatro cantos do mundo à procura de informações a respeito do inimigo. Embora disfarçados de vasos chineses, telefones, cadeiras, plantas, animais de estimação e até mesmo de outros seres humanos, eles ainda podiam ser reconhecidos por seu péssimo francês e inglês. Podiam ser reconhecidos, também, pelo forte acento russo ou alemão ao dizerem o próprio nome falso durante as apresentações de um jantar ou uma partida de xadrez com Tristan Tzara e Hugo Ball no café Terrasse, em Zurique (HUGNET, 1971, p. 24).

Nessa mesma época, André Breton, Louis Aragon, Philippe Soupault, André Desnos, Paul Éluard, Guillaume Apollinaire, Vicente Huidobro, César Vallejo, para citar apenas alguns poucos, refundavam a tipografia e as estratégias de edição e circulação de poesia com as publicações das revistas Dada, Nord-Sud, Proverbe e Favorables-París-Poema, difundindo o surrealismo e o dadaísmo por meio de assinaturas mensais ou semanais, cartazes, noitadas em cabarés, bares e cafés. Com isso: "A radiodifusão, o cinema, a máquina fotográfica de pequeno porte e o gramofone alargam consideravelmente o campo de atividade dos artistas, incitando-os a um trabalho coletivo de um novo gênero" (WILLETT, 1997, p. 48). Com John Heartfield, que integrava o grupo dadaísta de Berlim, a técnica da montagem revoluciona o design gráfico, tornando-se uma arma política de combate antifascista cada vez mais tragicômica ao longo dos anos que antecedem e durante os que perpassam a ascensão de 
Hitler ao poder. A ligação de Heartfield com o Partido Comunista Alemão (KPD) faz do seu trabalho um veículo de comunicação direta com o proletariado, utilizando uma linguagem breve, objetiva e irônica (Ibidem, p. 189-190).

Além do rearmamento alemão e do germe do antissemitismo que levaria Walter Benjamin ao suicídio em 1940, e paralelamente ao nascimento dos movimentos surrealista e dadá, em 1919, na Itália, Benito Mussolini fundou os Fasci Italiani di Combatimento, base do futuro Partido Fascista. Num curto período que compreende apenas três anos, Mussolini passou a comandar a Milícia Voluntária para a Segurança Nacional, conhecida como os "camisas negras", alcançando uma popularidade cada vez maior, até ser nomeado primeiro-ministro e obter poderes absolutos sobre o país. Essas forças organizavam-se na escuridão, ocultando suas verdadeiras motivações que levariam à prática de atrocidades inimagináveis até então. Um discurso estava à vista: propagandas, gritos de guerra, desejos de restauração da esperança e da grandeza de nações extremamente abatidas pela última grande guerra. Segundo Benjamin, a reação burguesa ao surrealismo e ao dadaísmo promoveu um "pogrom de poetas": "As editoras são atacadas, os livros de poemas lançados ao fogo, os poetas massacrados. E as mesmas cenas se dão ao mesmo tempo no mundo inteiro" (BENJAMIN, 1987a, p. 29). Quase uma década após esta fala presente no ensaio de Benjamin sobre o surrealismo, em 1938 ocorreu o intenso e sistemático pogrom da "Noite dos Cristais": "Em 9 de novembro de 1938, o regime nazista matou judeus, incendiou sinagogas, saqueou e destruiu lojas da comunidade judaica. O governo nazista impediu a ação de polícia e bombeiros" (BULAU, 2018, s.p.). Oitenta anos após a "Noite dos Cristais", em 9 de novembro de 2018, a chanceler alemã Angela Merkel discursou numa cerimônia memorial do Conselho Central dos Judeus. Ela advertiu que:

[...] em tempos de grandes mudanças sociais e tecnológicas, aumenta o risco de ascensão daqueles 'com respostas supostamente simples'. Ela afirmou ainda que a data de 9 de novembro deveria relembrar a todos 'que assistir passivamente a crimes e quebras de barreiras é, em última análise, um ato de cumplicidade'. (MERKEL, 2018, s.p.)

\section{EXPERIÊNCIA E VIDA LITERÁRIA}

Para Benjamin, a práxis surrealista evidenciava uma politização em certo estágio do seu desenvolvimento, uma passagem da esfera da arte para a esfera da política. Os 
indícios dessa passagem eram a implosão do domínio da literatura e a radicalização do modo de vida surrealista. O que interessava ao filósofo no processo de politização do surrealismo não era a produção de obras de arte, mas a prática de determinadas experiências. Segundo ele, com o movimento surrealista, "o domínio da literatura foi explodido de dentro, no momento em que um grupo homogêneo de homens levou a vida literária aos limites do possível” (BENJAMIN, 1987a, p. 22). Com isso, o ensaio publicado em 1929 defendia, a partir das experiências surrealistas, o surgimento de uma "política poética". Essa análise estava menos interessada no surrealismo como manifestação artística do que como manifestação política. Ela priorizou as experiências de um modo de vida, o comportamento social e a organização das ideias de um grupo em favor da transformação social; era uma análise materialista e antropológica, assim como a própria experiência do surrealismo. Ela situou historicamente o movimento surrealista, olhando para os seus agentes, para a construção de um ethos poético, uma "vida literária", o que é ao mesmo tempo surpreendente e confuso quando tentamos compreender uma das principais experiências do surrealismo apontadas por Benjamin em seus trabalhos: a "superação autêntica e criadora da iluminação religiosa", que se dá "numa iluminação profana, de inspiração materialista e antropológica" (Idem, ibidem, p. 23). Segundo Walter Benjamin, o êxtase e a embriaguez provocados pelo uso de narcóticos são uma espécie de "iluminação" que nada tem a ver com o sagrado, mas não é somente por meio das drogas que chegamos a essa "iluminação profana". Um dos seus traços fundamentais é a desestabilização das fronteiras entre "público" e "privado".

O que ocorre quando ponho em prática uma exposição necessária da minha intimidade? Pode ser que eu revele as minhas idiossincrasias, meus hábitos cotidianos, que deixe de lado categorias como a privacidade e a propriedade, que interrompem o intercâmbio afetivo e comportamental entre os indivíduos de um grupo ou comunidade. Exponho as minhas particularidades para que elas dialoguem com as diferenças e até mesmo para que sejam julgadas e sentenciadas nos tribunais duma sociedade tradicionalista e perversa. Em 1929, Walter Benjamin escreveu: "Viver numa casa de vidro é uma virtude revolucionária por excelência. A discrição no que diz respeito à própria existência, antes uma virtude aristocrática, transforma-se cada vez mais num atributo de pequenos burgueses arrivistas" (Idem, ibidem, p. 24). Talvez Benjamin não imaginasse o quanto a cotação da privacidade subiria na sociedade burguesa, a tal ponto 
que a vida íntima de famosos, e até mesmo a de desconhecidos, pudesse ser transformada num produto comercializável em reality shows e revistas "especializadas". No início do século XX, os surrealistas antecipavam conscientemente um debate que se tornaria central para a filosofia política contemporânea: a visibilidade e o reconhecimento de práticas, vivências e modos de vida, bem como o reconhecimento e a formação de corpos políticos individuais e coletivos. É o que Giorgio Agamben observou na experiência dos Situacionistas:

É curioso que, em Guy Debord, uma lúcida consciência da insuficiência da vida privada venha acompanhada da convicção mais ou menos consciente de que, neste caso, haveria, na própria existência ou naquela de seus amigos, algo único e exemplar, que exigia ser lembrado e comunicado. (AGAMBEN, 2017 , p. 11)

Mas essa tentativa de comunicação da vida privada esbarra sempre numa barreira e numa contradição: a clandestinidade que a torna incomunicável em sua própria condição obscura, pois a vida privada, segundo Agamben, "é tão íntima e próxima que, se tentarmos aferrá-la, nos deixa entre as mãos apenas a impenetrável e tediosa cotidianidade. Contudo, talvez seja exatamente essa homônima, promíscua, sombria presença que guarda o segredo da política" (Idem, ibidem, p. 11-12). É nesse sentido que a "intenção autobiográfica" e a pretensão de ser um "estatuto de verdade biográfica" foram apontadas por Giorgio Agamben como características centrais em certos trabalhos de Guy Debord. Para Agamben, os situacionistas procuravam na política a sua própria forma-de-vida, como se fosse possível alcançar por meio das relações público-afetivas de um coletivo uma brecha pela qual se pudesse entrever a luz do particular. A lógica do grupo em torno da qual os situacionistas se organizaram nos atribulados anos 1960 também foi um fundamento comum aos movimentos históricos de vanguarda. O estereótipo do artista solitário, recluso em seu escritório ou estúdio, na agonia fáustica da criação, foi inteiramente posto de lado, porque a convivência do grupo é a possibilidade do deslocamento necessário da política para o cotidiano individual; só assim a experiência do indivíduo pode se tornar uma revolução, uma "pequena iluminação" da esfera pública, que tende a ser cada vez mais distante em suas relações de poder e de organização social, que tende a negar e apagar as manifestações as discordantes e as formas-de-vida não hegemônicas. 


\title{
VIDRAÇARIA
}

A metáfora da "casa de vidro" usada por Walter Benjamin diz respeito a uma abertura pública das relações de afeto entre os membros de um determinado grupo. Práticas coletivas entraram em ação no modo de vida surrealista. "O vidro é em geral o inimigo do mistério. É também o inimigo da propriedade" (BENJAMIN, 1987a, p. 117). Ecos desse raciocínio de 1929 ressoaram em "Experiência e pobreza", de 1933, ensaio no qual também se discutiu a experiência "moderna" e seus desdobramentos artísticos e políticos. Ressoaram também no ensaio sobre a reprodutibilidade técnica da obra de arte, de 1936, quando Benjamin sugeriu que o valor de culto da obra de arte (experienciado por poucos, em ambientes fechados) dá lugar a um valor de exposição.

\begin{abstract}
Com efeito, assim como na pré-história a preponderância absoluta do valor de culto conferido à obra levou-a a ser concebida em primeiro lugar como instrumento mágico, e só mais tarde como obra de arte, do mesmo modo a preponderância absoluta conferida hoje a seu valor de exposição atribui-lhe funções inteiramente novas, entre as quais a 'artística', a única de que temos consciência, [e que] talvez se revele mais tarde como secundária. (Idem, ibidem, p 173)
\end{abstract}

Não se trata de uma superação absoluta de funções passadas. Em toda manifestação "artística", por mais contemporânea ou "atual" que seja, permanece um vestígio de magia e encantamento, um resíduo histórico que intervém na sua atualidade, podendo ser explorado arqueologicamente, não como origem ou essência, mas como categoria histórica, "construção teórica retrospectiva, post factum" (ANTELO, 2015, p. 16). Benjamin tinha uma intenção honestamente política quando escreveu suas teses sobre a reprodutibilidade técnica da obra de arte. Naquela altura, o atual estágio das condições de produção colocava para o crítico de arte e para os próprios artistas a tarefa de reavaliar a pertinência de certas categorias estéticas cristalizadas na teoria da arte e aplicadas indistintamente durante a análise das obras individuais. Dentre elas, Benjamin indica algumas noções ditas tradicionais "- como criatividade de gênio, validade eterna e estilo, forma e conteúdo - cuja aplicação incontrolada, e no momento dificilmente controlável, conduz à elaboração dos dados num sentido fascista" (Idem, ibidem, p. 166). Assim, era preciso recuperar o aspecto progressista das discussões em torno da obra de arte, elaborando conceitos que não só abrissem caminho para esse debate, abandonando categorias fossilizadas e politicamente estéreis, mas que também 
servissem à criação de "exigências revolucionárias na política artística" (Idem, ibidem). A mudança de perspectiva do exercício crítico proposta por Benjamin implicava a consideração das condições de produção como fatores constitutivos da obra de arte, de modo que, para compreendê-la em seu sentido político e evolutivo, fazia-se necessário um movimento de análise que rompesse com a noção de independência da arte em relação ao desenvolvimento da sociedade. Sem dúvida, podemos incluir ente os "conceitos tradicionais" apontados por Walter Benjamin a categoria de "aura", da qual a obra de arte teria sido emancipada pelos dispositivos de reprodução técnica.

Ao que parece, as categorias indicadas por Benjamin como "conceitos tradicionais" ocultavam a formação histórica e social dessas mesmas categorias, bem como sua relação com os meios artísticos disponíveis num determinado estágio de desenvolvimento da arte. Por esta razão, o crítico da arte devia assumir uma postura materialista diante de seu objeto, e a primeira evidência para essa guinada teórica foi sustentada por Benjamin na sua primeira tese, segundo a qual as condições de produção do capitalismo teriam permitido a criação de obras de arte em série. Além disso - e talvez esta seja a descoberta mais importante da tese benjaminiana -, nesta nova etapa evolutiva da arte, a própria reprodução técnica chega a "conquistar para si um lugar próprio entre os procedimentos artísticos" (Idem, ibidem, p. 167). Assim, o que a tese da reprodutibilidade técnica da obra de arte traz como argumento inicial é o fato de que as condições de produção, em regra, ou seja, sem exceção, são também meios artísticos, e a possibilidade da reprodução técnica é apenas um deles.

No entanto, somente num estágio avançado de sua evolução a reprodução técnica da obra de arte pôde se revelar como meio de produção. Esse estágio foi justamente o momento de atuação das vanguardas, bem como o estabelecimento da fotografia e do cinema. Segundo Benjamin, uma consequência direta do reconhecimento da reprodução técnica como meio artístico é sua independência em relação à "autenticidade" do original, definida por ele como "o aqui e agora da obra de arte, sua existência única, no lugar em que ela se encontra" (Idem, ibidem). Em virtude de sua capacidade de reapresentação de um objeto em dimensões espaciais e temporais em que o próprio original não poderia se realizar, a reprodução não pode ser vista meramente como uma cópia ou falsificação de uma determinada obra. Nesse sentido, a noção de autenticidade poderia ser transposta por analogia para a reprodução, já que ela tende a 
cumprir seu propósito independentemente do original, estabelecendo seu próprio "aqui e agora". Mas seria uma posição demasiadamente simplista e superficial encarar a categoria de autenticidade desta forma.

Em nota presente na terceira redação destas teses, Benjamin reafirmou que o autêntico escapa à reprodução, e, justamente por isso, a difusão dos procedimentos técnicos possibilitou a diferenciação e gradação da autenticidade de uma obra. Isto evidencia o abalo da noção de autenticidade e simultaneamente a sua instabilidade, de modo que as gradações do autêntico adquiriram extrema relevância para o comércio da arte. Contudo, a nota acrescentada por Benjamin na redação posterior das suas teses não explicitou o cerne da noção de autenticidade, que se apresentava como critério de valor intrínseco à obra de arte e revelava neste momento seu caráter de construção histórica, cujo valor anteriormente definido como essencial tem de ser reafirmado para cumprir uma finalidade mercadológica. "Sem dúvida uma imagem medieval da Virgem não era 'autêntica' - não o era ainda - na época em que se realizou; ela passou a ser autêntica no transcurso dos séculos seguintes" (Idem, 1983, p. 7).

O “aqui e agora" de uma obra, portanto, está carregado de elementos do passado, acumulados e levados adiante pela tradição. Aquilo que constitui hic et nunc a autenticidade de uma obra não nasceu com ela, e tampouco posso afirmar que esteve presente no instante de sua concepção. Só as condições de produção estiveram lá desde o início, como exigência mínima e fundamental para a existência da obra. Na minha opinião, a autenticidade e a singularidade não são inerentes a ela. Os procedimentos, por outro lado, são imprescindíveis, por isso o tratamento que os movimentos de vanguarda deram à obra de arte passava também por uma inclinação à transparência, à exposição do modus operandi.

Com efeito, o valor de exposição observado por Benjamin na obra de arte já vinha sendo anunciado em ensaios anteriores como um dos traços comportamentais dos grupos de vanguarda. Só em 1936, os dois conceitos parecem esbarrar um no outro, gerando um curto-circuito que poria à prova qualquer teoria contemplativa da arte. Isto ocorreu no preciso instante em que os dadaístas puderam ser considerados os precursores da cultura do choque instituída pelo cinema, alguns anos mais tarde, de forma definitiva e com o emprego de técnicas específicas. 
O dadaísmo ainda mantinha, por assim dizer, o choque físico embalado no choque moral; o cinema o libertou desse invólucro. Em suas obras mais progressistas, especialmente nos filmes de Chaplin, ele unificou os dois efeitos de choque, num nível mais alto. (Idem, 1987a, p. 192)

Em "Experiência e pobreza", Benjamin disse que: "As coisas de vidro não têm nenhuma aura" (Idem, ibidem, p. 117). O vidro é o material mais desqualificado para a produção de uma obra de arte do ponto de vista da "aura". O vidro das galerias, das passagens, da vida cotidiana e da consolidação do capitalismo, com a exposição da mercadoria, foi um material recorrente nos trabalhos de surrealistas e dadaístas. O vidro não é como o ouro da arte barroca, é um material comum, pouco venerável, sem valor de culto, sem valor artístico, mas com alto valor de exposição. Nesse sentido, não é imprudente afirmar que a implosão do domínio da literatura e a implementação de uma vida literária por parte das vanguardas sejam indícios da atribuição de um caráter secundário ao valor "artístico" das obras. Uma baixa valorização do "artístico" seguida de uma alta da "exposição" poderia fazer com que o meu olhar se concentrasse nos procedimentos e nos meios artísticos como um espectador desconfiado que busca descobrir as artimanhas utilizadas pelo ilusionista profissional. Em sua Teoria da Vanguarda, Peter Bürger observou que "os procedimentos individuais podem ser reconhecidos como meios artísticos a partir dos movimentos de vanguarda. Pois apenas nos movimentos históricos de vanguarda os meios artísticos, em sua totalidade, passam a estar disponíveis como tais" (2012, p. 46). É curioso que $O$ grande vidro, de Marcel Duchamp, cujo título é A noiva despida pelos seus celibatários, mesmo, tenha recebido um epíteto que destaca precisamente o material utilizado pelo artista e a proporção desse material. Afinal de contas, o que o espectador via ali, a não ser um grande vidro “que não tem nenhuma aura"? Talvez o trabalho de Duchamp sugira "que a 'obra' seja o procedimento para se fazer obras, sem a obra. Ou com a obra, mas só como um apêndice documental que sirva apenas para deduzir o processo do qual saiu" (AIRA, 2007, p. 12). Talvez esse processo de desvalorização do "artístico" tenha suas raízes na potencialização romântica de um sujeito ético como centro da práxis poética. Schiller, Baudelaire e Rimbaud seriam alguns de seus precursores.

Efetivamente, não há produto da arte moderna, não há impulso emocional, não há impressão ou disposição de ânimo do homem moderno, que não deve sua sutileza à sensibilidade nervosa que tem sua origem no Romantismo. 
Toda a exuberância, anarquia e violência da arte moderna [...] procedem do Romantismo. (HAUSER, 1976, p. 342)

\section{AUTOEXÍLIO}

Em Poesia ingênua e sentimental, Friedrich Schiller indicou uma crise do sujeito moderno: a natureza não é mais uma parte constitutiva do homem, como havia sido para os antigos. A cultura clássica não havia degenerado de todo a sensibilidade e o sentimento ingênuo, bases de uma vida social e de uma mitologia. A natureza, para Schiller, é sempre maior e mais nobre do que a arte, e é do lado da primeira que devemos estar, encarando a sua ingenuidade (espontaneidade e perfeição) desde um ponto de vista moral, e não estético; pois o que há de admirável nela são as ideias que temos a seu respeito e não a sua existência em si mesma. "Como esse interesse pela natureza funda-se numa ideia, ela pode se manifestar apenas em espíritos sensíveis às ideias, isto é, em espíritos morais" (SCHILLER, 1941, p. 18). Trata-se de uma contradição aparente, mas ela reforça a teoria da poesia sentimental - aquela que procura uma emoção lírica através da arte e da razão - como uma teoria fundamentalmente idealista. O poeta sentimental, segundo Schiller, relaciona-se por meio da reflexão com uma natureza idealizada que remonta à Antiguidade clássica. Afirmar essa relação como construção ou posicionamento moral equivale à negação de uma essência ou de uma ideia imutável da natureza. Isto revela um pressuposto ontológico elaborado a partir de uma práxis nem sempre restrita ao trabalho intelectual. Como práxis, ela se estende para a vida privada e para os hábitos cotidianos. O conceito de natureza elaborado por Schiller subentende uma natureza perfeita, por isso os atributos que admiro nos objetos da natureza são os atributos que me faltam. Devo reconhecer a perda da natureza, a minha pobreza, a discordância que tenho com relação ao meu próprio ser; devo constatar que sou um ser imperfeito e finito, assim como concluiu Descartes, por outras vias, na sua terceira meditação metafísica, tomando como parâmetro para a imperfeição humana a perfeição e a infinitude de Deus (DESCARTES, 1824 , p. 290). Surge, então, a minha necessidade de deslocamento para fora do "Eu". Preciso estabelecer relações com o mundo exterior, com a linguagem, com a sociedade, com os objetos. Há uma cisão constitutiva entre mim e a natureza. A minha condição melancólica e nostálgica diante dessa natureza perdida me impele a transformar o 
trabalho poético numa operação reflexiva e crítica da precariedade por força da própria precariedade da minha condição humana. Mas se acredito que a experiência moderna é uma experiência baseada na cultura e no artifício, se reconheço as transformações que a cultura opera no espírito humano, não posso deixar de reconhecer as transformações da própria natureza, que sofre a ação da cultura e age sobre ela. Isto me conduz a pensar, desde uma perspectiva romântica, que não seria exatamente a perda da natureza aquilo que constitui a minha experiência como sujeito moderno, mas a perda de uma certa natureza, não menos idealizada, com as quais os Antigos se relacionavam. Baseando-se no paradigma de uma natureza idealizada, Schiller instaura uma tensão permanente entre ideal e realidade. Esse ideal é, ao mesmo tempo, uma crítica à minha condição de homem moderno e a hipostasia de um conceito transformada em princípio criativo. Proveniente de um paradoxo ideológico, a teoria estética de Schiller torna-se um princípio de organização da vida. Assim, a visão romântica da "realidade" converteu-se em um exercício poético indissociável deum pressuposto moral que exige ao poeta um exercício crítico dessa mesma "realidade". Nessas circunstâncias, a única opção para o poeta romântico é se lançar em direção aos objetos do mundo exterior, e, nesse movimento para fora, ele mesmo se ver como um objeto. "Desde o Gótico, o desenvolvimento da sensibilidade não tinha recebido um impulso tão forte, e o direito do artista de seguir a voz dos seus sentimentos e sua disposição individual provavelmente nunca foi acentuado de maneira tão incondicional" (HAUSER, 1976, p. 341). Daí a justificada referência feita por Rimbaud aos poetas românticos na sua conhecida carta de 15 de maio de 1871, endereçada a seu amigo Paul Demeny.

\section{O POETA DA PÓLIS}

1. O reconhecimento de que o "Eu é um outro" (RIMBAUD, 1951, p. 254) explica a lição tomada por Rimbaud dos românticos: eles sabiam que "a canção é muito poucas vezes a obra" (Idem, ibidem, p. 253).

2. Rimbaud percebeu no romantismo um "caráter destrutivo" ainda latente. "O espírito de destruição é romântico", (1951, p. 31) dirá Jean Cocteau, em 1922, ao avaliar com alguma dose de conservadorismo estético o combate das vanguardas à "instituição Arte". 
3. A leitura de Rimbaud destacou uma dimensão ética no romantismo, o que serviu ao seu interesse de legitimar a participação do poeta na pólis, e, consequentemente, a sua função social. "A arte eterna teria suas funções," ele escreveu, “como os poetas são cidadãos" (1951, p. 256). Com essa fórmula, o poeta e militante da Comuna de Paris se contrapôs a uma experiência estética pura, separada da práxis vital, desenvolvida pelo esteticismo.

4. Rimbaud enfatizou os princípios românticos de união entre arte e vida, de deslocamento do sujeito e de busca por novas "ideias e formas" (Idem, ibidem) que atendessem à sua subjetividade e sensibilidade críticas.

5. O pensamento "cantado e compreendido" (Idem, ibidem, p. 253) dos românticos ao qual Rimbaud se referiu não tem implicação direta em uma ideia fechada de obra: a canção nem sempre é o poema.

6. O título de "rei dos poetas" (Idem, ibidem, p. 257) concedido por Rimbaud a Baudelaire em sua carta vem seguido por uma cuidadosa ressalva. Segundo ele, apesar de ter sido o rei dos poetas, Baudelaire teria vivido num meio demasiado artístico.

\section{EMBRIAGUEZ}

Em Os paraísos artificiais, Baudelaire observou que há momentos nos quais nos encontramos num "estado excepcional do espírito e do sentido", (BAUDELAIRE, 1900, p. 9) um estado "paradisíaco", ele escreveu, "se eu o comparo às pesadas trevas da existência comum e cotidiana" (Idem, ibidem). Essa experiência, assim definida, em termos misteriosos, é uma espécie de iluminação "explosiva" e "gloriosa" (Idem, ibidem). Ela se assemelha a um despertar transcendental, um arrebatamento, uma percepção aguda do mundo exterior que se oferece para mim "com um relevo pulsante, uma clareza de contornos, uma riqueza de cores admiráveis" (Idem, ibidem, p. 9). Mas essa experiência extraordinária não é um privilégio de santos e devotos. Não é uma recompensa que devo receber em troca "da prece assídua e dos ardores espirituais" (Idem, ibidem, p. 10). Ela se dá espontaneamente, em situações nem sempre místicas ou religiosas, por força da imaginação ou do acaso. Procuro multiplicar, estender a duração ou o número de ocorrências dessa "iluminação profana". Invento formas de me induzir a esse estado prodigioso do espírito, busco "na ciência física, na farmacêutica, nos mais 
grosseiros licores, nos perfumes mais sutis", (Idem, ibidem, p. 11) uma forma de "criar o paraíso [...], como um maníaco que substituísse móveis sólidos e jardins verdadeiros por cenários pintados numa tela e expostos numa moldura" (Idem, ibidem). Baudelaire analisou duas dessas formas de indução: o haxixe e o ópio, relatando suas origens, seus métodos de utilização e seus diversos efeitos sobre a sensibilidade humana. Michel Butor observou que o livro:

[...] é formado por dois quadros confrontados: $\mathrm{O}$ poema do haxixe e $\mathrm{O}$ comedor de ópio, cada um traz um elogio da droga, seguida de sua condenação, mas, atenção, ela não é condenada segundo as regras da moral burguesa, ela é condenada, ela é vencida pela poesia, que é mais forte do que ela. (BUTOR, 1971, p. 12)

\section{O SONHO ABSURDO}

É certo que Benjamin tinha em mente a "monografia da embriaguez" (BAUDELAIRE, 1900, p. 6) escrita por Baudelaire quando afirmou que o haxixe e o ópio podem servir de propedêutica à "iluminação profana" revelada pela embriaguez surrealista (BENJAMIN, 1987b, p. 248-255). Com efeito, Baudelaire fez questão de assinalar em Os paraísos artificiais as diferenças entre os sonhos que tenho enquanto durmo e as alucinações do haxixe. Durante o sono, posso ter uma espécie de "sonho natural" (BAUDELAIRE, 1900, p. 18) em que entrevejo a minha vida comum, as minhas preocupações, os meus desejos e vícios combinados de uma forma mais ou menos bizarra com os objetos vistos durante o dia. Mas há também outra espécie de sonho, "o sonho absurdo, imprevisto, sem relação nem conexão com o carácter, a vida e as paixões de quem dorme! esse sonho [...] representa evidentemente o lado sobrenatural da vida, e é justamente porque ele é absurdo que os antigos o consideraram divino" (Idem, ibidem).

A experiência dessa segunda classe de sonho foi buscada pelos surrealistas de maneira programática. Eles a transformaram numa forma-de-vida, extraíram de suas energias um movimento em direção aos objetos. Eles buscavam o lado sobrenatural da vida, mas sem o sonho e sem a droga. Buscavam-no materialista e antropologicamente na vigília, nas ruas, casas, automóveis, lojas, pedras e relógios. Paralelamente, eles fizeram desse movimento uma estética. 
Baudelaire define uma arte surgida da fantasia criativa como: surnaturalisme. Entende-se por este termo, uma arte que "desobjetiva" as coisas em linhas, cores, movimentos, acidentes cada vez mais independentes e que projetam sobre ela aquela "luz mágica" que aniquila sua realidade no mistério. Do surnaturalisme, Apollinaire derivará, em 1917, o surréalisme - e com razão , pois com ele designa a continuação do que queria Baudelaire. (FRIEDRICH, 1991, p. 56)

\section{ILUMINAÇÃO PROFANA}

O objetivo de Baudelaire ao escrever Les paradis artificiels era despertar o interesse do "amador distinto" para o arrebatamento da experiência poética; seu alvo era aqueles que consideravam a poesia um "divertimento superficial": uma quinquilharia para espíritos ociosos (BUTOR, 1971, p. 9-10). Sua estratégia, então, baseou-se numa analogia entre a embriaguez do haxixe e do ópio e a embriaguez provocada pela poesia. Em As flores do mal, Baudelaire já havia construído essa analogia a partir da embriaguez do vinho, que cantava ao homem "Um canto cheio de luz e de fraternidade!” (BAUDELAIRE, 1917, p. 215) É preciso que o homem o beba, prove dos seus inumeráveis prazeres: "Para que do nosso amor nasça a poesia,/ Que se abrirá pra Deus como uma rara flor!" (Idem, ibidem, p. 216).

Em Spleen de Paris, Baudelaire voltou a incitar a embriaguez de todos, desta vez com o poema em prosa "Encham a cara". Para Baudelaire, a embriaguez seria capaz de nos tirar de um estado subalterno em relação ao tempo. Seria preciso, para não sentir o fardo do tempo, estar sempre embriagado. Não qualquer tempo, mas o tempo rígido, entediante e opressor do trabalho e dos compromissos sociais; contra eles, contra a cronologia e a ditadura das horas, era preciso entregar-se a uma embriaguez sem trégua. Segundo Baudelaire, quando perguntamos à natureza "que horas são?", “o vento, a vaga, a estrela, o relógio", todos respondem: "é hora de encher a cara; para não serem mais os escravos martirizados do tempo, encham a cara, encham a cara sem parar, de vinho, de poesia, de virtude, do jeito que quiserem" (Idem, 1917, p. 122). Esse estudo baudelairiano da embriaguez seria aprofundado quase que cientificamente em um livro antropológico sobre a natureza da poesia, do haxixe e do ópio. Contudo, se o objetivo inicial de Baudelaire foi valorizar a poesia apontando a superioridade da sua "iluminação" quando a comparamos à embriaguez de outras drogas, o efeito teve uma contraparte dialética aparentemente imprevista.

Ou talvez não. 
Talvez Baudelaire soubesse que operava um dispositivo de profanação da poesia ao deslocá-la da esfera do sagrado para um espaço ao lado de elementos terrenos como o vinho, o haxixe e o ópio. Pelo mesmo dispositivo, ao comparar esses elementos profanos à poesia, Baudelaire introduziu neles um traço incongruente do sagrado. Essa operação neutralizou a "iluminação religiosa", restituindo-a ao uso comum dos homens (AGAMBEN, 2007). Qualquer homem poderia, a partir daí, fazer como Noé que, após o dilúvio, plantou um vinhedo, bebeu vinho e embebedou-se. Mas é preciso alguma cautela antes de concluir desta profanação um movimento de democratização da arte.

O que Baudelaire descobriu, consciente ou inconscientemente, parece ter sido o fato de que não preciso do culto à poesia nem de qualquer espécie de culto religioso ou dogmático para que eu seja, de algum modo, "iluminado", para que eu deixe de ser um escravo do "tempo"... Posso, pela embriaguez, "criar o paraíso" à minha maneira. Nada mais agonístico, nada mais revolucionário aos olhos do jovem Rimbaud, que partia de Charleville a caminho da Comuna de Paris e escreveu ao amigo Paul Demeny: "Baudelaire é o primeiro vidente, rei dos poetas, um verdadeiro Deus" (RIMBAUD, 1951, p. 257).

\section{EMBRIAGUEZ E REVOLTA}

"O Poeta se torna vidente", escreveu Rimbaud, "mediante um longo, imenso e pensado desregramento de todos os sentidos. Todas as formas de amor, de sofrimento, de loucura; ele busca a si mesmo, esgota em si todas as drogas [poisons], para reter apenas a sua quintessência" (Idem, ibidem, p. 254). Não haveria um resumo mais preciso para Os paraísos artificiais de Baudelaire: não é à droga que o poeta deve aderir, mas à sua quintessência, à revelação de uma sensibilidade expandida e a uma multiplicação da personalidade na qual ele encontra a potencialização extraordinária de si mesmo.

Ao perceber a potência de subversão política do cotidiano na dialética da embriaguez, Baudelaire e Rimbaud trabalharam no sentido de demonstrar a disponibilidade dos meios para se atingir uma "iluminação profana"; tal disponibilidade - assim como a disponibilidade sobre os meios artísticos - só seria percebida em sua totalidade posteriormente, com os dadaístas e surrealistas. 


\begin{abstract}
Em todos os seus livros e iniciativas, a proposta surrealista tende ao mesmo fim; mobilizar para a revolução as energias da embriaguez. Podemos dizer que é essa a sua tarefa mais autêntica. Sabemos que um elemento de embriaguez está vivo em todo ato revolucionário, mas isso não basta. Esse elemento é de caráter anárquico. Privilegiá-lo exclusivamente seria sacrificar a preparação metódica e disciplinada da revolução a uma práxis que oscila entre o exercício e a véspera da festa. [...] De nada nos serve a tentativa patética de apontar no enigmático o seu lado enigmático; só devassamos o mistério na medida em que o encontramos no cotidiano, graças a uma ótica dialética que vê o cotidiano como impenetrável e o impenetrável como cotidiano [...] O homem que lê, que pensa, que espera, que se dedica à flânerie, pertence, do mesmo modo que o fumador de ópio, o sonhador e o ébrio, à galeria dos iluminados. E são iluminados mais profanos. Para não falar da mais terrível de todas as drogas - nós mesmos - que tomamos quando estamos sós. (BENJAMIN, 1987a, p. 32-33)
\end{abstract}

Essa crítica ao caráter anárquico do elemento de embriaguez presente em todo ato revolucionário é direcionada sobretudo à sua abstração. Seria fácil transformar a embriaguez ou a iluminação profana da poesia numa atitude contemplativa ou carnavalesca. Para Walter Benjamin, a tarefa surrealista mais autêntica era mobilizar a energia da "embriaguez" para a revolução (Idem, ibidem, p. 29). Mas para que essa embriaguez tenha um efeito real de ordem política, é necessária a sua compreensão como um método "organizado" [raisonné] de experimentação do corpo e dos espaços do corpo; assim, torna-se necessária a sua aplicação no obscuro cotidiano da vida privada e nos acontecimentos coletivos. "Também o coletivo é corpóreo" (Idem, ibidem, p. 35).

Em termos comparativos, o gesto de revolta pode ser encarado como um movimento de dança; nele, exponho o meu corpo e a sua mobilidade imprevista, garanto a sua visibilidade no espaço político e o seu papel na sociedade. A dança é uma maneira de fazer determinada atividade ou produto e como tal é uma forma de arte. "Ao teatro e à escrita, Platão opõe uma terceira forma, uma boa forma de arte, a forma coreográfica da comunidade que dança e canta sua própria unidade" (RANCIÈRE, 2009, p. 18). A forma coreográfica tem um "movimento autêntico, o movimento próprio dos corpos comunitários" (Idem, ibidem). É um movimento livre das fronteiras do simulacro que oferece à minha percepção um déjà-vu: o já-posto, o já-identificado. O movimento coreográfico cria formas de reconhecimento e identidades inexploradas, reinventando o corpo em cada gesto. 
Tornar o elemento de embriaguez do ato de revolta uma "dança habitual", cotidiana, é uma tarefa política; e ela só pode ser cumprida mediante um uso do corpo capaz de desativar tanto a contemplação do corpo sagrado quanto a submissão do corpo instrumentalizado pelo trabalho.

\section{IDEAL E ABISMO}

A "carta do vidente" de Arthur Rimbaud parece apontar para uma desvalorização do "artístico". O futuro da poesia passa pela criação de novas "ideias e formas" capazes de contemplar uma experiência do sujeito fora de si. A experiência estética não se limita ao poema e este não se limita a existir como obra fechada, regida por regulamentos internos, cujo conteúdo é a própria arte. Talvez por isso Rimbaud tenha terminado sua carta anunciando a sua ida à Paris. Os poemas que ilustram a sua dissertação sobre a "poesia nova" projetam os seus ideais de poeta e cidadão comprometido. O dadaísmo e o surrealismo seguiram os passos de Rimbaud e do romantismo. Com eles, a saída de si do sujeito lírico empreendida pelos românticos ganhou proporções ainda maiores. Paralelamente ao desalojamento do sujeito lírico de uma "interioridade pura", (COLLOT, 2013, p. 22) os modernos afastaram-se pouco a pouco de uma ideia de "poesia pura", cuja radicalização foi a "antipoesia", a "antiarte", ou, em termos benjaminianos, a "política poética" de certos movimentos de vanguarda. É o que se discutia, em 1935, no texto de abertura do primeiro número da revista Caballo verde para la poesía, publicada em Madrid, sob a direção de Pablo Neruda:

É muito conveniente, em certos momentos do dia ou da noite, observar profundamente os objetos em repouso: as rodas que viajaram longas distâncias empoeiradas, suportando grandes cargas vegetais ou minerais, sacos de carvão, barris, cestas, os cabos e alças dos instrumentos do carpinteiro. A partir deles vem o contato do homem e da terra como uma lição para o torturado poeta lírico. As superfícies usadas, o desgaste que as mãos infligiram sobre as coisas, a atmosfera muitas vezes trágica e sempre patética desses objetos infunde uma espécie de atração não negligenciável para a realidade do mundo.

A impureza confusa dos seres humanos é percebida neles, o agrupamento, uso e desuso de materiais, pegadas e dedos, a constância duma atmosfera humana inundando as coisas de dentro para fora.

Assim seja a poesia que buscamos, passada como por um ácido pelos deveres da mão, penetrada pelo suor e pela fumaça, cheirando a urina e a lírio, manchada pelas diversas profissões exercidas dentro e fora da lei. 
Uma poesia impura como um terno, como um corpo, com manchas de nutrição e atitudes vergonhosas, com rugas, observações, sonhos, vigília, profecias, declarações de amor e ódio, feras, batidos, idílios, crenças políticas, recusas, dúvidas, afirmações, impostos. (NERUDA, 1935, p. 7)

Baseando-se, como o romantismo, numa relação entre sujeito e objeto, a poesia “impura como um terno" buscada pelas vanguardas planejava reverter o paradigma instaurado por Friedrich Schiller. A natureza idealizada não é mais um parâmetro para o juízo da realidade. A poesia não se mantém intacta nem é mais percebida como puro processo intelectual, separado duma práxis, de modo que a crítica da "realidade" só teria os efeitos de uma dialética negativa na medida em que esta "realidade" se apartasse de um ideal preexistente ou de uma idealidade vazia.

\begin{abstract}
Assim ocorre por toda parte em Baudelaire. A idealidade vazia tem origem romântica. Mas Baudelaire dinamiza-a a uma força de atração que despertando uma tensão excessiva para cima, repele o homem que está em tensão para baixo. É, como o mal, uma coação a qual se tem de obedecer, sem que aquele que a obedece venha a se relaxar. Daí a paridade de "ideal" e "abismo", daí expressões "ideal corroente", "estou acorrentado à fossa do ideal", "azul inacessível”. Tais expressões são conhecidas também dos místicos clássicos, mas neles designavam a violência da graça divina que causa dor e prazer, o estágio que antecede a beatitude. Em Baudelaire, os dois polos, tanto o mal satânico quanto a idealidade vazia, têm o sentido de desvelar aquela excitação que possibilita a fuga do mundo banal. Porém a fuga é sem meta, não vai além da excitação dissonante. (FRIEDRICH, 1991, p. 48-49)
\end{abstract}

Com as vanguardas, o ideal e a idealidade vazia cederam espaço para uma poesia na qual não existem pressupostos. Não há fuga ideal nem excitação dissonante, mas permanência e gozo. A "lição para o torturado poeta lírico" de que fala Neruda desprende-se dos objetos e corresponde materialmente às suas especificidades. A própria realidade torna-se matéria poética. O elemento ideal - seja ele pressuposto, como a natureza de Schiller, ou vazio, como o "abismo" de Baudelaire - dá lugar à vida e à contingência, como na teoria do poeta sórdido, formulada por Manuel Bandeira em "Nova poética", poema de 1949:

\footnotetext{
Vou lançar a teoria do poeta sórdido.

Poeta sórdido:

Aquele em cuja poesia há a marca suja da vida.

Vai um sujeito,

Sai um sujeito de casa com a roupa de brim branco muito bem [engomada, e na primeira esquina passa um caminhão, salpica-lhe o [paletó ou a calça de
} 
uma nódoa de lama:

É a vida.

O poema deve ser como a nódoa no brim:

Fazer o leitor satisfeito de si dar o desespero.

Sei que a poesia é também orvalho.

Mas este fica para as menininhas, as estrelas alfas, as virgens cem por cento e as amadas que envelheceram sem maldade. (BANDEIRA, 1993, p. 205)

\section{DEMOLIÇÕES}

Em 1936, ano de eclosão da Guerra Civil espanhola, Paul Éluard fez uma conferência em Londres por ocasião de uma exposição surrealista organizada por Roland Penrose. Nela, Éluard posicionou-se - exatamente como Neruda - em favor de uma poesia aberta à comunidade e à vida. "Chegou o tempo em que todos os poetas têm o direito e o dever de defender que estão profundamente fincados na vida dos outros homens, na vida comum" (1968, p. 513). Nesse ponto, é preciso lembrar a força e a influência exercidas pela figura de Paul Valéry sobre a poesia francesa na primeira metade do século XX, dado que ressalta o teor político e provocativo da conferência realizada em Londres por Éluard, sobretudo quando diz que: "Todas as torres de marfim serão demolidas, todas as palavras serão sagradas e o homem, estando enfim de acordo com a realidade, que é sua, não terá mais que fechar os olhos para que se abram as portas do maravilhoso" (Idem, ibidem, p. 514).

Ir para a vida comum significa abrir campos diversos de circulação da poesia, redistribuir os papéis do poeta na sociedade, reconfigurar os mecanismos de percepção crítica e reinterpretar os objetos da subjetividade lírica a partir de uma perspectiva terrena. "Depois de mais de cem anos", escreveu Paul Éluard, "os poetas desceram dos cumes sobre os quais acreditavam estar. Eles foram para as ruas [...]" (Idem, ibidem, p. 521). España en el corazón e Canto general, de Pablo Neruda, assim como España, aparta de mí este cáliz, de César Vallejo, são resultados dessa poética cujo funcionamento corresponde a um modo de vida ou a uma "política poética". Essas obras reescrevem ou continuam a escrever o "Chant de guerre parisien" de Arthur Rimbaud. Por isso as "novas ideias e formas" de que falou Rimbaud em sua "carta do vidente" são permanentemente buscadas, nunca encontradas; "talvez possamos descrever a vanguarda, de modo mais preciso, como uma tentativa de acelerar a lógica do 
‘transitório' [...], de estabelecer uma estética e uma política da 'atualização"” (SICAR, 2016, p. 75). Isto se traduz na bibliografia dos poetas que Rimbaud chamou "videntes", nas diferenças estéticas perceptíveis entre Flores do mal e Spleen de Paris, entre Uma estação no inferno e Iluminuras, que legitimam a profanação do verso metrificado e a exploração da escrita do "poema em prosa". Quando abandono o ideal, o que me resta é uma eterna busca, uma mudança constante que segue as contradições e as intempéries da vida cotidiana, além de suas repercussões na sensibilidade e no espírito. "O poeta deve ser um vidente de novas formas de vida", disse Nicanor Parra. "Ao expressar o sórdido, o ambíguo, as frustrações da alma contemporânea, almejo a sua superação" (PARRA, 1959, s.p.).

Em março de 1920, Tristan Tzara publicou um "Manifesto do movimento Dadá" no qual dizia que: "Dadá não é uma escola literária", mas “o cameleão da mudança rápida e interessada” (TZARA, 1920, p. 5). Ao apostar nessa mudança permanente, na instabilidade, na reformulação e profanação dos topoi da tradição artística ocidental, as manifestações dadaístas e surrealistas seriam o terceiro estágio da autocrítica da arte iniciada pelos românticos, cujo primeiro estágio é a saída do sujeito lírico de uma interioridade pura e o segundo estágio a saída da poesia de uma poesia pura. Além disso, a fórmula l'art pour l'art "raramente foi tomada em sentido literal, quase sempre foi um simples pavilhão de conveniências, sob o qual circula uma mercadoria que não podemos declarar, porque não tem nome" (BENJAMIN, 1987 a , p. 27). O “antipoeta" e o "antiartista" fogem constantemente da própria poesia e da própria arte numa errância por terrenos desconhecidos. E embora eles possam voltar ao seu ponto de partida, à escrita do poema ou à manifestação artística, eles jamais se permitem traçar o mesmo caminho. Em regra, esta é uma operação arriscada, por ele vivem como "um bailarino à beira do abismo" (PARRA, 1969, p. 184). Paradoxalmente, esse risco de cair no abismo é antes procurado do que evitado. Arthur Rimbaud, nesse sentido, foi capaz de saltar de cabeça em direção ao abismo, sem rodeios, a fim de desaparecer para sempre na vida comum. Contudo, no início, até mesmo ele tinha o seu futuro como incerto: “[...] em oito horas eu estarei em Paris", ele escreveu ao final da carta enviada a Paul Demeny em 15 de maio de 1871, finalizando-a com um desconfiado e desconcertante "talvez" (RIMBAUD, 1951, p. 258). 


\title{
RECOMEÇO
}

Se for verdade que "as vanguardas apareceram quando se deu por encerrada a profissionalização dos artistas, sendo necessário começar de novo", (AIRA, 2007, p. 11) também é verdade que houve nesse processo uma renovação da concepção de origem frente ao acúmulo da cultura dos séculos passados. "A profissionalização pôs em risco a historicidade da arte; encerrou o histórico ao conteúdo, deixando a forma petrificada. Equivale dizer que se rompeu a dialética forma-conteúdo, que origina o artístico da arte" (Idem, ibidem, p. 12). Nessa época, Benjamin escreveu que "em seus quadros e narrativas, a humanidade se prepara, se necessário, para sobreviver à cultura. E o que é o mais importante: ela o faz rindo" (BENJAMIN, 1987a, p. 119).

As vanguardas avançaram a partir do zero, realizando um desmesurado e sanguinolento potlatch da cultura e da civilização passada. "Quem quiser que fique com a cultura burguesa degenerescente", elas disseram, com o decidido intuito de construir outra a partir das ruínas e da pobreza da anterior, ainda que essa outra fosse uma espécie de "simulacro" ou "pantomima", como afirma César Aira, (AIRA, 2007, p. 11) num raciocínio do qual tendo a discordar, pelo menos em parte.

\begin{abstract}
Pensemos nos esplêndidos quadros de Ensor, nos quais uma grande fantasmagoria enche as ruas das metrópoles: pequenos-burgueses com fantasias carnavalescas, máscaras disformes brancas de farinha, coroas de folha de estanho, rodopiam imprevisivelmente ao longo das ruas. Esses quadros são talvez a cópia da Renascença terrível e caótica na qual tantos depositam suas esperanças. Aqui se revela, com toda clareza, que nossa pobreza de experiência é apenas uma parte da grande pobreza que recebeu novamente um rosto, nítido e preciso como o do mendigo medieval. (BENJAMIN, 1987 a , p. 115)
\end{abstract}

Com a "pantomima" de seus quadros, Ensor introduziu um elemento fantasmagórico nos ritos de celebração burguesa. Ela não reproduz a carnavalização nem a "galvanização" de um estado de pobreza; em seus quadros, a fantasmagoria alucinada das máscaras disformes revela uma dimensão grotesca e diabólica do humano. Algo terrível se anuncia. Além das máscaras brancas de farinha, máscaras feitas com crânios humanos reforçam o terror da multiplicação da persona; mas, em lugar de ocultar, elas revelam o interior por detrás da máscara que é o nosso próprio rosto. A “cópia”, nesse caso, é uma diferença (SANTIAGO, 2000, s.p.) que deixa transparecer como o vidro transparente - a deterioração e a morte. Feitas com crânios de animais ou 
de humanos, as máscaras xamânicas de certas sociedades tribais denotam a ambivalência existencial do sacerdote, condenado a uma intermitência perpétua entre o mundo dos vivos e o mundo dos espíritos. É assim que as máscaras dos quadros de Ensor denunciam as contradições morais e estéticas da pequena-burguesia e da sua esperança ilusória. Nos quadros de Ensor, como nos contos e romances de Franz Kafka, a esperança é apenas um mito. Toda esperança gloriosa é convertida em fantasmagoria e desespero, num riso grotesco e reticente. Isto também ocorre nas fotomontagens realizadas por John Heartfield a partir da chegada de Hitler ao posto de chefe do governo da Alemanha, em janeiro de 1933. Nesses trabalhos, o elemento fantasmagórico é materializado nas imagens recorrentes de caveiras que representam a violência, a guerra, o terror e a crise econômica. Mas, apesar do aspecto terrível dessas figuras, a percepção de que elas contêm um traço ridículo e pueril é praticamente inevitável. Essa percepção é resultado direto da manipulação das imagens realizada por Heartfield durante o processo de montagem; também contribuem para ela a construção narrativa da própria montagem e a disposição das legendas que direcionam a interpretação do espectador para um lugar entre a ingenuidade festiva da piada e a sobriedade angustiante da tragédia (WILLETT, 1997, p.113-163). Um verso de Nicanor Parra descreveu bem essa condição ambivalente do indivíduo que se depara com a sua própria barbárie. "Até as caveiras riem de mim”, ele disse. Contudo, não se trata de um riso alegre e carnavalesco, mas sim de um riso contraditório e indeciso, acompanhado por "lágrimas de sangre" (PARRA, 1969, p. 226).

\section{Referências}

AGAMBEN, Giorgio. Profanações. São Paulo: Boitempo, 2007. [E-book]

AIRA, César. Pequeno manual de procedimentos. Curitiba: Arte \& Letra, 2007.

ANÔNIMO. Em carta inédita, Einstein alerta para ameaça nazista. DW Brasil. 2018. Disponível em: https://www.dw.com/pt-br/em-carta-in\%C3\%A9dita-einstein-alertapara-amea\%C3\%A7a-nazista/a-46227936. Acesso em: 9 nov. 2018.

ANÔNIMO. Merkel diz que pogrom de 1938 foi prenúncio do Holocausto. DW Brasil. Disponível em: https://www.dw.com/pt-br/merkel-diz-que-pogrom-de-1938-foipren\%C3\%Bancio-do-holocausto/a-46228774. Acesso em: 9 nov. 2018. 
ANTELO, Raúl. Archifilologías latinoamericanas. Lecturas tras el agotamiento. 1. ed. Villa María: Eduvim, 2015.

BAUDELAIRE, Charles. Les paradis artificiels. Paris: Baudinière, 1900.

BAUDELAIRE. Le spleen de Paris, ou Les cinquante petits poèmes en prose de Charles Baudelaire. Paris: Émile-Paul, 1917.

BAUDELAIRE. Les fleurs du mal. Paris: Librairie des bibliophiles parisiens, 1917.

BENJAMIN, Walter. "A obra de arte na época de suas técnicas de reprodução". In: BENJAMIN, Walter et al. Textos escolhidos: Walter Benjamin, Max Horkheimer, Theodor W. Adorno, Jürgen Habermas. 2. ed. São Paulo: Abril Cultural, 1983, p. 3-28.

BENJAMIN, Walter. Imagens do pensamento. Sobre o haxixe e outras drogas. 1. ed. Belo Horizonte: Autêntica, 2015.

BENJAMIN, Walter. Magia e técnica, arte e política, ensaios sobre literatura e história da cultura. Obras escolhidas, vol. 1. 7. ed. São Paulo: Brasiliense, 1987.

BENJAMIN, Walter. Rua de mão única. Obras escolhidas, v. 2. São Paulo: Brasiliense, 1987.

BULAU, Doris. 1938: O pogrom da "Noite dos Cristais". DW Brasil. Disponível em: https://www.dw.com/pt-br/1938-o-pogrom-da-noite-dos-cristais/a-672173. Acesso em: 9 nov. 2018.

BÜRGER, Peter. Teoria da vanguarda. São Paulo: Cosac Naify, 2012.

BUTOR, Michel. Essais sur les modernes. Paris: Gallimard, 1971.

COCTEAU, Jean. Poésie critique I. Paris: Gallimard, 1951.

COLLOT, Michel. “O sujeito lírico fora de si”. Signótica, v. 25, n. 1, p. 221-241, 2013.

DESCARTES, René. Euvres de Descartes, Tome I. Paris: Victor Cousin, 1824.

ÉLUARD, Paul. Oeuvres complètes, tome I. Paris: Gallimard, 1968.

FRIEDRICH, Hugo. Estrutura da lírica moderna. 2. ed. São Paulo: Duas Cidades, 1991.

Recebido em: 03/12/2020 Aceito em: 04/01/2021

\footnotetext{
${ }^{1}$ Agradeço imensamente a Luciana di Leone e Eduardo Coelho, professores do Departamento de Ciência da Literatura da Faculdade de Letras da UFRJ, pelas leituras atentas, críticas e sugestões ao longo da produção desta pesquisa.
} 